\title{
Men buying sex. Differences between urban and rural areas in UK
}

Article

Accepted Version

Della Giusta, M., Di Tommaso, M. L. and Jewell, S. L. (2017) Men buying sex. Differences between urban and rural areas in UK. Urban Studies, 54 (3). pp. 713-729. ISSN 1360-063X doi: https://doi.org/10.1177/0042098016645267 Available at https://centaur.reading.ac.uk/62260/

It is advisable to refer to the publisher's version if you intend to cite from the work. See Guidance on citing.

To link to this article DOI: http://dx.doi.org/10.1177/0042098016645267

Publisher: Sage

All outputs in CentAUR are protected by Intellectual Property Rights law, including copyright law. Copyright and IPR is retained by the creators or other copyright holders. Terms and conditions for use of this material are defined in the End User Agreement.

\section{www.reading.ac.uk/centaur}

\section{CentAUR}

Central Archive at the University of Reading

Reading's research outputs online 
Men buying sex. Differences between urban and rural areas in UK

\author{
Marina Della Giusta (Department of Economics, University of Reading), Maria Laura Di \\ Tommaso (Dept of Economics and Statistics Cognetti de Martiis, University of Turin and \\ Collegio Carlo Alberto) and Sarah Louise Jewell (Department of Economics, University of \\ Reading)
}

\title{
1. Introduction
}

In the context of this special issue on cities as sites for the realisation and reproduction of social norms and attitudes around sexuality and desire, we focus on the role that social norms and attitudes have in men's purchase of sexual services, building on both our theoretical and empirical work on the demand for paid sex (Della Giusta et al. 2009a, 2009b). Here we use a sample of British men surveyed in the 1999-2001 British National Survey of Sexual Attitudes and Lifestyles (Natsal II). Although the data is a decade old (a more recent wave of the survey has been conducted but not made available for use), it has the benefit of being a nationally representative survey and thus permits to reach rather more reliable conclusions than some of the smaller ad hoc surveys, as well as predating legislative changes that have since sought to criminalize clients and that are still being implemented across several English counties.

Wider social norms around the sex industry both underpin and reflect the views of participants in the industry as well as those of society, thus the extent to which prostitution is seen as an activity to be condemned or as simply a part of the entertainment industry matters enormously to individual participation and the beliefs of those who purchase sex. As discussed in Della Giusta and Munro (2008) and Della Giusta (2009), the regulatory framework within which prostitution takes place in England and Wales has undergone significant changes in recent years. The data we use here reflects the legislative approach in place before the so called abolitionist turn, which has followed since the so called Swedish approach became popular with British policy makers. In 2004 the government conducted the Paying the Price consultation and the resulting legislation sought to introduce a markedly more negative stance towards the industry and clients in particular, and a view of sex workers as essentially victims. These changes followed the 
Swedish model on the basis of a rather uninformed assessment of both its effects in Sweden and its suitability to the UK situation.

The Home Office prostitution Strategy for England and Wales (2006) contained as a key element 'tackling demand', which was seen alongside 'reducing supply' as crucial to eradicating street prostitution and challenging the view that street prostitution is inevitable. The Strategy formally endorsed measures such as prosecutions under the kerb crawling legislation, local media campaigns including 'naming and shaming' and 'kerb crawler re-education programs'. The Strategy also gave room to the implementation, in several parts of the country, of a raft of prosecution for kerb crawling offences, under the Sexual Offences Act 1985. The Criminal Justice and Police Act 2001 strengthened the previous regulation and made the offence arrestable, giving the courts have the power to disqualify drivers. Similarly, in October 2007, the policing Minister in Northern Ireland announced that kerb crawling would be introduced into law as a specific offence. In Scotland, the Prostitution (Public Places) Scotland Act 2007 came into force in October 2007; it criminalised 'loitering or soliciting in any public place for the purpose of obtaining the services of someone engaged in prostitution.' (Sanders and Campbell, 2008). Campaigning is now calling for paying for sex to be made a crime. ${ }^{1}$ Whilst the focus here is on clients, it is important to acknowledge that the effects on sex workers have been very significant: Sanders and Campbell (2008) illustrate the implications of this shift for the rights, safety and working conditions of sex workers and the increase in their stigmatization, whilst Di Tommaso et al.(2009) found that women who are trafficked for sexually exploitation were worse off in terms of health, abuse, and freedom of movement when they work in a secluded space.

Our analysis builds on both our theoretical and empirical work on modelling the demand for paid sex (Della Giusta et al. 2009a, 2009b) and we extend it by considering the effects of risky behaviours and attitudes to relationships and to women on demand. We find that those who declare to have purchased sex have both different socio-demographic characteristics (being on average older, with fewer children, more educated but with lower professional status), and different sexual and risky behaviours as well as attitudes to relationships. As expected in the light of findings in the literature (well summarised in the 2004 Urban Studies special issue and in

$1 \quad$ (http://www.bbc.co.uk/news/uk-29720915). 
more recent literature), we find a clear city effect in the sample, mostly driven by London, which goes beyond the attitudes captured in the survey and thus combines a mixture of factors related to the supply of paid sex and unobserved characteristics of city dwelling respondents.

\section{The demand for paid sex}

Findings from empirical studies of clients suggest that personal characteristics (personal and family background, self-perception, perceptions of women, sexual preferences), economic factors (education, income, work), as well as attitudes towards risk (health hazard and risk of being caught where sex work is illegal), lack of interest in conventional relationships, desire for variety in sexual acts or sexual partners, and viewing sex as a commodity, are all likely to affect demand.

Cameron and Collins (2003) model male clients' decision to enter the market for prostitution services, where he has the choice to derive utility from one relationship partner and/or one paid sex partner. They distinguish between the motivations of men in relationships (variety, specific acts, frequency, outlet for stress) and single men ('relative search costs of finding willing sexual partners, or partners willing to engage in specific sexual activities in an ad hoc or formal social context, and in a given time period.'). Pitts et al. (2004) surveyed a sample of 1225 men and women in Australia and found that $23.4 \%$ had paid for sex at least once. They reported paying for sex to satisfy sexual needs $(43.8 \%)$, because paying for sex is less trouble $(36.4 \%)$, and because it is entertaining (35.5\%). Significantly, the researchers found that there were not many significant differences between men who had paid for sex and those who had not, except that the ones who had were on average older, less likely to have university education and to have had a regular partner in the previous year.

The motivations of sex workers' clients in the UK (who were all males and appeared to be representatives of all sectors of society) studied in the course of a programme on the sex industry presented by Channel 4 appeared to convey the impression that a connection existed between the effort and costs associated with finding a sexual partner who would readily satisfy their sexual preferences, and the straightforward and readily accessible option of sex work. Similar findings are reported by Coy, Horvath and Kelly (2007) on buyers of sex in East London, as well as by Campbell (1998) and Sanders (2008). This is confirmed by Thorbek and Pattanaik (2002), who 
draw a sort of "psychological" profile of male sex tourists on the basis of their own descriptions of themselves and accounts of their experiences. This indicates that many of them are finding relationships with others very difficult (either because they do not have the time or the skills required to meet people) and choose sex tourism as an "easier" alternative, which does not imply any responsibility towards the person providing the sexual service.

As for the views they held of sex workers, it appears that both sexism and racism mix in determining a very marked distancing, which allow sex tourists to practically ignore and show no interest in the lives and working motivations of the sex workers whose services they buy. Wider phenomena connected to consumerism and globalization are also clearly related to this industry, which reflects multiple power structures: Marttila (2003) concludes from her study of Finnish clients that: "the sex business is first and foremost about gendered, economic, social and cultural - global and local - power structures." (Marttila 2003, 8). Thus, different intersections of gender, race and class all contribute to the creation of 'othering' mechanisms that serve to both distance the parties to an exchange and justify the assertion of economic power within it. This phenomenon is obviously not limited to paid sex exchanges, and has been widely documented across a range of personal services.

Stigma is not just at play with men: women clients are also engaging in sex tourism, as documented both in Thorbek and Pattanaik (2002), and in Sanchez Taylor (2001). The latter, in particular, offers a more in-depth analysis of North American and Northern European women buying sex work services of young men in the Caribbean, in what they themselves describe as 'romance holidays'. Responses to her interviews suggest that, on the one hand, women clients are mostly reluctant to define what they engage in as prostitution, and, on the other, that their ideas about the young men whose service they buy are deeply rooted in racist ideas about black men and black men's sexuality. The theme of inequality appears to be at the core of the relationship: prejudices that allow the stigmatization of another person as fundamentally "different" and inferior to oneself appear again and again in customers' accounts (Ben-Israel et al. 2005; Pitts et al. 2004; Kern 2000; Blanchard 1994).

Studies have recently begun to appear that address more explicitly attitudes and their relationship to the regulation of prostitution: Kuosmanen (2011) reviews existing studies of attitudes to prostitution in Sweden finding more support for criminalization as a result of the introduction of 
the law, and also conducts a random sample study finding more support for the current Swedish law among women and younger respondents and a small effect of higher education on women's attitudes. Jahnsen (2008), reviewed in Jakobsson and Kotsadam (2011) finds for Norway that women and those living in the capital region are more in favor of criminalizing clients, as are feminists, left-wing sympathizers, and Christians. Jakobsson and Kotsadam (2011) use data for Norway and Sweden find that men and sexual liberals are more positive toward prostitution, that both conservatives and those supporting gender equality are more negative toward prostitution, and that holding anti-immigration views is correlated with more positive attitudes toward buying sex.

In the UK, Ward et al. (2005) use the 1999-2001 British National Survey of Sexual Attitudes and Lifestyles (Natsal II) to explain the increase in sexually transmitted infections and risky sexual behaviours and they find an increase between 1990 and 2000 in the number of men reporting paying for heterosexual sex, with the typical client being between 25 years and 34 years, never or previously married, and living in London, and no association with ethnicity, social class, homosexual contact, or injecting drug use. They also found that men who paid for sex were more likely to report 10 or more sexual partners in the previous 5 years and that only a minority of their lifetime sexual partners $(19.3 \%)$ were commercial with only $15 \%$ reported having had an HIV test.

In what follows we estimate the probability of ever paying for sex as a function of a range of personal socio-demographic indicators, sexual and other behaviours and attitudes to relationships and women.

\section{Data set and modeling strategy}

The data is drawn from the 1999-2001 British National Survey of Sexual Attitudes and Lifestyles (Natsal II), the second cross section of a series of surveys, of which the first was conducted in 1990-91. The surveys are conducted by the Centre for Sexual Health and HIV Research at University College London, with the data collected through face-to-face interviews ${ }^{2}$.

\footnotetext{
2 http://www.ucl.ac.uk/sexual-health/research/sex-attitudes.htm"http://www.ucl.ac.uk/sexual-health/research/sexattitudes.htm
} 
The sample size for the 1999-2001 survey is 12,110 individuals aged 16-44 living in private households. Unfortunately, only men were asked whether they had ever paid for sex, which does not allow us to test in what ways female clients differ from males. Given the findings of previous research with this data (Ward at al., 2005), we concentrate on men between age 26 and 44, so our resulting sample of men includes 3084 observations.

The main advantage of this dataset with respect to the ones utilized for previous studies is that it is a national representative sample of sexual attitudes and it includes questions on paying for sex. We are able to, therefore, study clients versus non-clients while most papers (including Della Giusta et al. 2009b) analyze clients using datasets that only contains clients. A drawback of our data is there are no questions related to the frequency of paid sexual encounters, as the question only asks if the (male) individual has ever paid for homosexual or heterosexual sex. We thus estimate a probit model where the dependent variable is equal to 1 if the man has ever paid for sex. We adjust all calculations to allow for the stratification, clustering and weighting of the data, in particular to adjust for over-sampling of some groups such as those in London and ethnic minorities. Men who have paid for sex constitute 12.9 percent of our sample, and given that our sample is representative of the entire British population between age 26 and 44, we can infer that 13 percent of British men have paid for sex at least once in their life. Despite the relatively small age range of our sample we include age of clients, which in previous studies was found to be an important determinant of the demand for paid sex

As discussed in the introduction the British National Survey on Sexual Attitudes and Lifestyles does not contain data on income or price for paid sex, therefore as proxies for income we include controls for educational levels (whether respondents hold a degree, A-levels, O-levels or no qualifications). Following Della Giusta et al. (2009a), we are interested in whether having a higher professional status means being more sensitive to the stigma from paying for sex, assuming that men with a high professional status (managers or professionals) have reputations that can be easily damaged by being found to be clients.

In order to test if paying for sex is correlated with risky behaviours, we use make use of five variables: sex with foreign partners, unsafe sex, smoking habits, use of injected drugs, and

A third survey was conducted in 2010-2012 but this data were not available when this article was written . 
alcohol consumption.

We also want to see to what extent demand for paid sex is a substitute or complement to free sex, so we include three variables: number of heterosexual partners in the last year, number of occasions of heterosexual sex in the last 4 weeks and a dummy for marriage or co-habitation.

Since the sociological literature on clients (Sanders 2008) shows paying for sex is more frequent among those individuals who had their first intercourse at a younger age, we also include dummies for age of first heterosexual intercourse.

Finally, as we are interested in the effect of living in urban areas on demand, we include both a variable classing respondents as living in London, Urban or city centre (not London), Suburban residential and Country town or village.

We also include some indicators of attitudes to relationships, which are typically believed to be more open in an urban environment, and use importance of income and children as proxies for importance of relationships (sharing chores, mutual respect, same tastes, sex, faithfulness are all insignificant to explaining demand so we exclude them from our model) and whether respondents believe that unfaithfulness is wrong.

One major problem in utilising the above mentioned variables is that some of the variables refer to a certain period in the past (last year, last 4 weeks, ever in the past) and some variables refer to the current period (time of the interview). Therefore some of the correlations that we will highlight in the results of the probit model are somehow spurious because for instance we regress the variable" ever paid for sex" on the variable " belong to a religion now" or professional status now.

We begin by looking at how the characteristics vary by urban area type: Table 1 includes descriptive statistics of men by four types of areas: London, Urban/city center not London, Suburban residential, and Country town/Village. The table also report tests of differences between London and elsewhere. The proportion of men who have paid for sex is higher in urban areas, especially in London, and the difference in statistically significant.

TABLE 1 APPROXIMATLY HERE 
The characteristics of men do vary across the different urban areas: a higher proportion of individuals have a degree in London, and there is also a higher proportion of individuals in a Professional, Technical or managerial positions. Those in urban areas and in particular London have had more sexual partners in the previous year and are more likely to have had a partner outside of the UK but have had sex on fewer occasions in the last four weeks. Those living in Urban and city centres (not London), in particular, exhibit more risky behaviours with a higher number smoking, consuming alcohol and having unsafe sex. They are also less likely to be married or cohabiting. Those living in London tend to have an intermediate position in these variables between Urban /city centre and the other categories.

Table 2 shows descriptive statistics of clients versus non clients, where clients are defined as men who declare to have paid for sex at least once in their life, and it reports as well a test of differences between clients and non-clients Firstly, we note that, as table 1 suggested, the distribution of urban area type and region vary between clients and non-clients, and in particular clients are more likely to be living in London than non-clients (the dummy variable for London is statistically different for clients and non-clients at a 1 percent level).

\section{TABLE 2 APPROXIMATLY HERE}

The average age of men who had paid for sex at least once in their life is very similar to the average age of men who had not. Given that older men would have had more opportunity to have ever paid for sex because they lived longer, we would have expected that the age of clients was higher than the age of non-clients but this is not the case. It could be due to the fact that our sample only includes men below 44 years old. A previous study of US clients (Della Giusta et al. 2009b) shows that age is positively correlated with paying for sex, therefore we can reasonably expect that ours is a lower bound estimate of the number of men paying for sex.

Clients are also more educated than non-clients, possibly also capturing an income effect: 15 percent of the clients have a-levels or an equivalent degree, against only 11 percent of the nonclients; among the clients only 15 percent do not have any education, while this is the case for 18 
percent of the non-clients. There are very small differences in skills and professional profiles: clients are more un-skilled and partly skilled than non-clients. For instance, 6 percent of the clients are unskilled, while this is the case for only 4 percent of the non-clients; 7 percent of clients have a professional or managerial position as opposed to 9 percent of non-clients. In terms of demographic characteristics, clients have fewer children than non-clients, and 71 percent of clients are married or co-habiting as opposed to 83 percent of non-clients, and are

slightly more religious (45 per cent versus 41 percent of non-clients), confirming the profiling done by Ward et al. (2005).

When looking at behaviours, we see clearly that clients are on average less risk averse than nonclients: they smoke more (43 percent of clients are smoker and only 36 percent of non-clients), had more unsafe sex last year (14 percent of clients against 6 percent of non-clients), and use more drugs ( 6 percent of clients have ever injected drugs as opposed to 3 percent of non-clients). Clients are also on average more likely to have a high or medium level of alcohol consumption (21 percent as opposed to 14 percent) and also had less heterosexual sex in the last 4 weeks (perhaps indicating a substitution effect), but they had more sex partners in the last year (suggesting they like variety). Clients are more religious but they hold less conservative views about sex before marriage, homosexual sex, and abortion. Finally, 36 percent of clients had their first sexual intercourse at an age between 13 and 15 (as opposed to 26 percent of non-clients).

\section{Results}

We now move to our model of the demand for paid sex and present our results in Table 3. Since our variable of interest is a binary variable we estimate our model using a probit model. A binary probit allows us to model the probability of having ever paid for sex and makes use of an underlying latent variable which determines whether or not an individual has ever paid for sex. Whilst one can interpret the sign and significance of the coefficients of a probit model, the magnitude of the raw coefficients are not intuitive, therefore we report average marginal effects (an average across the marginal effect for each individual) that provide the effect of a change in an explanatory variable on the probability of having paid for sex. So for example, an increase in age by one year will increase the probability of paying for sex by 0.4 percentage points. 
Table 3 presents the marginal effects for five different specifications of the model: specification 1 includes only the demographic variables, specification 2 includes some variables about risky behavior, specification 3 adds some variables related to other sexual behaviors, and finally specification 5 includes some dummies for the age of first intercourse and attitudes towards relationship. We note that the model is rather robust to the different specifications as the size and the significance of the coefficients are fairly stable across the specifications. The last column with the most comprehensive model is our preferred specification because some of the variables included only in this last model appear to be significant, suggesting the other models are biased because they are underspecified.

\section{TABLE 3 APPROXIMATELY HERE}

Age has the expected (positive) sign which confirms previous results (Della Giusta et al. 2009b). Each year increases the probability of ever having paid for sex by 0.3-0.4 percent. The positive effect of age does not necessarily mean that older men demand more paid sex; this result could also be due to a longer spell of life for older men and therefore it is more likely that they have paid for sex in the course of their life.

The probability of having paid for sex decreases in a range between 1 and 1.4 with one more child. The child variable refers to the number of natural children ever had, including still born and dead children. This effect could be due to an income effect and a time constraint, as well as possibly different values: giving importance to children for as successful relationship decreases the probability of being a client by 2.3 percentage points. Being married or co-habiting is not statistically significant in the last three specifications, but thinking that unfaithfulness is wrong decreases the probability of being a client by 2.6 percentage points. The importance of sharing chores, of mutual respect and of sex to a successful relationship were all insignificant in all specifications, and thus excluded from the results.

As expected in the light of findings in the literature (well summarised in the 2004 US special 
issue and in more recent literature) we find a London effect in the sample. This result varies with the different specifications. In particular the dummy for London loses its statistical significance and its absolute value decreases from 5.4 percent to 3.1 percent (from spec. 1 to spec. 2) when the variables related to risky behavior are introduced. The value remains approximately the same in Spec. 3, 4, and 5 and in specification 5 becomes again statistical significant at 10 percent level. So London respondents are 5.4-2.9 percentage points (according to different specifications) more likely to pay for sex with the remaining areas insignificant.

The evidence from the sex trade indicates that London is a fast moving market in which there is a high variety and turnover of both clients and sex workers, as well as a much higher proportion of both migrant and male sex workers than in the rest of the country (Balfour and Allen, 2014), making it quite distinct from both the supply and demand perspective. It is thus possible that a different regulatory regime would be appropriate for inner London, particularly given the transient nature of its population and the fact that at least part of the sex industry is firmly connected with the tourism business. We cannot verify the latter as the government office region measure of London refers to greater London and not just Inner London, however as a robustness check we test the effect of regions and find that paying for sex is again less likely in Wales/Scotland and more likely in London (with Wales or Scotland as the base category), confirming our results.

The education dummies show that having a high school diploma increases the probability of having paid for sex by around 5-6 percent (according to the different specifications) with respect to uneducated individuals. In the fifth specification having a university degree increases the probability of being a client by 4 percent and it is statistical significant at 10 percent level. This is also mirrored by the attitude to income variable, which suggests clients think income is more important to a successful relationship than non-clients. These results confirm the findings for the US clients in Della Giusta et al. (2009b).

The variables related to the professional status show that the higher the status of the client, the lower the probability of paying for sex. Individuals with a professional/managerial position are 5-6 percentage points less likely to pay for sex than unskilled individuals; similar results to those of Della Giusta et al. (2009b) and of Jones et al. (2014) on NATSAL III 
The indicators for risky behavior show there is a high correlation among different types of risky behavior and paying for sex; for instance, smokers have a probability of paying for sex which is 2 percent higher than for non-smokers. Having injected drugs implies a probability of paying for sex which is 6-7 percent higher than for those who have not injected drugs. We find similar effects for alcohol consumption and unsafe sex. The literature on health and paid sex (Rao et al., 2001) shows the presence of a premium for unprotected paid sex, and recent work by Regushevskaya and Tuormaa (2014) shows that although Finnish clients are aware of health risks they grossly underestimate its importance and even hold false belief about HIV transmission and even resistance to HIV. Our results strengthen these by showing the correlation across a wider range of risky behaviours.

Having had a sexual partner from outside the UK increases the probability of paying for sex by 11-12 percent. The number of new heterosexual partners in the last year has a very small absolute value and it is positively and significantly related to the demand for paid sex, supporting the contention that another component may be the desire for variety (as in Cameron and Collins, 2003).

Having had the first intercourse between 13 and 15 years old increases the probability of having paid for sex by 4 percentage points.

The parameter for religion is positive and statistically significant at 5 percent level, implying that being religious increases the probability of paying for sex. All the other variables related to conservative opinions are not statistically significant. This may be seen to run counter to the results in Jacobsson and Kotsadam (2011), who find a connection between degree of conservatism and views on prostitution. Nevertheless, they do not link the degree of conservatism to actual demand as we do, they test the effect of being religious and being from the right or the left on attitudes towards prostitution among Norwegian and Swedes. So they do not test behaviors.

Our results therefore show that showing conservative views and paying for sex are not correlated and moreover that the probability of paying for sex is positively correlated with being religious.

Finally, to delve deeper into the London effect, we separate the London and non-London 
subsample and model separately the probability of being a client (Table 4). A Chow test has an F test of 0.71 with a $p$ value of 0.86 so there is no evidence that there are systematic differences in the coefficients between London and the non-London sample. The only difference that is significant is having a university degree which is significantly different between the two samples at the $10 \%$ level ( $\mathrm{p}$ value $(0.0541)$ with an f-test of 3.72 .

Table 4 APPROXIMATLY HERE

\section{Conclusions}

In this paper, we have focussed on UK clients' behaviors which affect their demand for paid sex in a sample drawn from the British National Survey of Sexual Attitudes and Lifestyles (Natsal). The survey was conducted in 2000-2001 by the Centre for Sexual Health and HIV Research at University College London, interviewing 12,110 people aged 16-44 years, and contained several socio-demographics, health and sexual life information, as well as some attitude questions, all of which can be used to analyse differences between those who declare to have paid for sex to those who have not. As this is a national representative sample, we can study clients versus non clients while most papers (including Della Giusta et al. 2009b) analyze clients with data sets that contains only clients, making it impossible to draw conclusions that can be applied to wider populations. The survey does not specifically focus on sex work, thus we do not have detailed data on prices paid or types of sex, however we have a large set of information on respondents and their sexual lives, preferences and a range of other behaviours. Furthermore, we have information on their attitudes to relationship and to women in particular. Men who declare they have paid for sex constitute 12.8 percent of our sample. Since our sample is representative of the entire British population between age 26 and 44, we can infer that 13 percent of British men (in this age interval) have paid for sex at least once in their life (as discussed in Ward et al., 2005). Here we want to look at urban versus non-urban consumers of paid sex and test the effect of their attitudes, risky behaviors and personal characteristics on the demand for paid sex. We run regional robustness checks and find an effect from living in London, which has often been discussed as a market that differs from the rest of the country in the literature on paid sex (Coy, 
Horvath and Kelly (2007)). This effect loses statistical significance when we control for risky behavior. We contribute to the discussion on sex, consumption and the city by focussing on the roles of attitudes and risky behaviours in the consumption of paid sex and observe how these factors matter in determining consumption and how cities and particularly London affect the demand for paid sex in ways that are independent of a range of attitudes, behaviours and personal sociodemographic characteristics, suggesting that London dwellers are different or are immersed in a very different environment, both in terms of the market for sexual services and the norms governing sexual behaviour, as suggested in the literature on the making of urban economies (Brown, 2000; Collins, 2004a and 2004b; Johnston and Longhurst, 2009; Hubbard, 2012). Our results suggest that prostitution policy cannot be homogenously designed for urban and rural areas, and especially that a prostitution policy designed for London is unlikely to have the same effects in other parts of the country. This is important in the context of recent discussions on the reintroduction of red light districts in some UK cities.

\section{Bibliography}

Balfour, R. and Allen J. (2014). A review of the literature on sex workers and social exclusion, UCL Institute of Health Equity.

https://www.gov.uk/government/uploads/system/uploads/attachment_data/file/303927/A_Revie w_of_the_Literature_on_sex_workers_and_social_exclusion.pdf

Brown, M. P. (2000). Closet space: Geographies of metaphor from the body to the globe London: Routledge.

Ben-Israel, H. and Levenkron N. (2005). "The Missing Factor: Clients of Trafficked Women in Israel's Sex Industry", unpublished manuscript, Hebrew University in Jerusalem.

Blanchard, K. (1994). "Young Johns" Mademoiselle 100(5), 1994. 
Cameron, S. andCollins A. (2003). 'Estimates of a Model of Male Participation in the Market for Female Heterosexual Prostitution Services,' European Journal of Law and Economics $16: 3,271-288$.

Campbell, R. (1998). "Invisible men: making visible male clients of female prostitutes in Merseyside.”, in Prostitution: On Whores, Hustlers and Johns, Prometheus, Amsherst, NY.

Collins, A. (ed.) (2004). 'Sex and the City,' Urban Studies 41:9

Collins, A. (2004). Sexuality and sexual services in the urban economy and socialscape: an overview. Urban Studies, 41(9), 1631-1641.

Coy, M., Horwarth, M., Kelly, L. (2007). It's just like going to the supermarket: Men talk about buying sex in East London. Child and Woman Abuse Studies Unit, London.

Della Giusta, M. and V. Munro Eds. (2008). The Supply-Demand Dynamic in Prostitution, Ashgate.

Della Giusta, M., M.L. Di Tommaso, and S. Strøm (2009a). 'Who is Watching? The market for prostitution services.' Journal of Population Economics, 22 (2): 501-516.

Della Giusta, M., M.L. Di Tommaso, I. Shima and S. Strøm (2009b). 'What money buys: clients of street sex workers in the US' Applied Economics, 41 (18): 2261-2278.

Della Giusta, M. (2009) 'Simulating the Impact of Regulation Changes on the Market for Prostitution Services', European Journal of Law and Economics. Di Tommaso, M.L., Shima I., Strøm S., Bettio F., (2009). As bad as it gets. Well-being deprivation of sexually exploited 
trafficked women. European Journal of Political Economy 2009, vol. 25, pp. 143-162.

Home Office prostitution Strategy for England and Wales (2006) http://www.popcenter.org/problems/street_prostitution/PDFs/Home\%200ffice_prostitution_200 6.pdf

Hubbard, P. (2012). Cities and sexualities. London: Routledge.

Jakobsson, N. \& Kotsadam, A, (2011). "Gender Equity and Prostitution: An Investigation of Attitudes in Norway and Sweden" Feminist Economics, Vol 17, pp.31-58.

Johnston, L., and Longhurst, R. (2009) Space, place, and sex: Geographies of sexualities. New York: Rowman \& Littlefield.

Jones, K G, A. M.Johnson, K. Wellings, P. Sonnenberg, N. Field, C. Tanton, B. Erens, S.g Clifton, J. Datta, K. R Mitchell, P Prah, C H Mercer (2014). The prevalence of, and factors associated with, paying for sex among men resident in Britain: findings from the third National Survey of Sexual Attitudes and Lifestyles (Natsal-3). Sexually Transmitted Infection, doi:10.1136/sextrans-2014-051683

Kern, R.M. (2000). 'Prostitute Client Profiles: Indicators of Motivations for Prostitution Use,' Archives of Sexual Behaviour 29:2, 165-177.

Kuosmanen, J. (2011). Attitudes and perceptions about legislation prohibiting the purchase of sexual services in Sweden. European journal of social work. 2011 vol. 14 (2), 247263 
Marttila, A.M. (2003), Consuming Sex: Finnish Male Clients and Russian and Baltic Prostitution. Presented at Gender and Power in the New Europe, the 5th European Feminist Research Conference August 20-24, 2003 Lund University, Sweden.

National Centre for Social Research et al. , National Survey of Sexual Attitudes and Lifestyles II, 2000-2001 [computer file]. Colchester, Essex: UK Data Archive [distributor], August 2005. SN: 5223.

Pitts, M K., A M.A. Smith, M O’Brien, and S Misson (2004). "Who pays for sex and why? An analysis of social and motivational factors associated with male clients of sex workers", Archives of Sexual Behaviour, 33 (4): 353-358.

Rao, V., Gupta, I., Lokshin, M. \& Jana, J. (2001). ‘Sex Workers and the Cost of Safe

Sex: The compensating Differential for Condom Use in Calcutta' (Mimeo: World Bank).

Regushevskaya, E and T Tuormaa (2014). How do prostitution customers value health and position health in their discussions? Qualitative analysis of online forums, Scand J Public Health November 2014 vol. 42 no. 7 603-610.

Sanchez Taylor, J. (2001). 'Dollars are a Girl's Best Friend? Female Tourists' Sexual Behaviour in the Caribbean,' Sociology: Identity Politics in the Workplace 35:3, 749-764.

Sanders, T. (2008). Paying for Pleasure: Men who buy sex, Willan, Cullompton.

Sanders, T. and Campbell, R. (2008). Why Hate Men who Pay for Sex? Investigating the shift to tackling demand and calls to criminalise paying for sex, in Demanding Sex? Critical 
reflections on the supply/demand dynamic in prostitution, Munro V (ed.) Ashgate

Thorbek, S. \& Pattanaik, B. (eds.) (2002). Transnational Prostitution: Changing Global Patterns (London: Zed Books).

Ward, H. C H Mercer, K Wellings, K Fenton, B Erens, A Copas, A M Johnson (2005). Who pays for sex? An analysis of the increasing prevalence of female commercial sex contacts among men in Britain, Sex Transm Infect 2005;81:467-471 doi:10.1136/sti.2005.014985 
Table 1: Characteristics of our Sample of Men by Urban Area Type

\begin{tabular}{|c|c|c|c|c|c|}
\hline & London & $\begin{array}{l}\text { Urban/city } \\
\text { centre - } \\
\text { not } \\
\text { London }\end{array}$ & $\begin{array}{l}\text { Suburban } \\
\text { residential }\end{array}$ & $\begin{array}{l}\text { Country } \\
\text { town/village }\end{array}$ & \\
\hline Ever paid for sex & 0.16 & 0.12 & 0.10 & 0.10 & $* * *$ \\
\hline Age & 34.40 & 34.73 & 34.81 & 35.09 & $* *$ \\
\hline Number of Children & 0.93 & 1.35 & 1.32 & 1.40 & $* * *$ \\
\hline$=1$ if ever married, 0 otherwise & 0.56 & 0.62 & 0.71 & 0.74 & $* * *$ \\
\hline$=1$ if never married but ever cohabited, 0 otherwise & 0.16 & 0.13 & 0.14 & 0.11 & * \\
\hline$=1$ if Degree level qualification; $=0$ otherwise & 0.41 & 0.21 & 0.21 & 0.23 & $* * *$ \\
\hline$=1$ if a-levels/as-levels/slc higher grade; $=0$ otherwise & 0.11 & 0.10 & 0.12 & 0.11 & \\
\hline$=1$ if 0 -level/other; $=0$ otherwise & 0.34 & 0.46 & 0.50 & 0.48 & $* * *$ \\
\hline$=1$ if No education; $=0$ otherwise & 0.14 & 0.23 & 0.17 & 0.18 & $* *$ \\
\hline$=1$ if Professional $/$ managerial; $=0$ otherwise & 0.12 & 0.07 & 0.09 & 0.07 & $* * *$ \\
\hline$=1$ if Technical/Managerial; $=0$ otherwise & 0.43 & 0.27 & 0.32 & 0.34 & $* * *$ \\
\hline$=1$ if skilled manual or non-manual; $=0$ otherwise & 0.33 & 0.45 & 0.42 & 0.42 & $* * *$ \\
\hline$=1$ if partly skilled; $=0$ otherwise & 0.07 & 0.15 & 0.12 & 0.12 & $* * *$ \\
\hline$=1$ if unskilled; $=0$ otherwise & 0.04 & 0.05 & 0.05 & 0.05 & \\
\hline $\begin{array}{l}=1 \text { if partner outside UK in the last } 5 \text { years; }=0 \\
\text { otherwise }\end{array}$ & 0.21 & 0.13 & 0.09 & 0.09 & $* * *$ \\
\hline$=1$ if had unsafe het. sex in last year; $=0$ otherwise & 0.06 & 0.08 & 0.07 & 0.05 & \\
\hline$=1$ if ever a smoker; $=0$ otherwise & 0.57 & 0.57 & 0.53 & 0.54 & \\
\hline $\begin{array}{l}=1 \text { if ever injected drugs or other substances; }=0 \\
\text { otherwise } \\
=1 \text { if high or medium alcohol consumption; }=0\end{array}$ & 0.04 & 0.04 & 0.03 & 0.03 & \\
\hline otherwise & 0.15 & 0.17 & 0.14 & 0.14 & \\
\hline No. of new het. sex partners, last year & 0.66 & 0.62 & 0.38 & 0.34 & $* * *$ \\
\hline Number of occasions of het. sex in last 4 weeks & 5.63 & 6.35 & 5.69 & 5.92 & \\
\hline $\begin{array}{l}=1 \text { if belongs to any religion now; }=0 \text { otherwise } \\
=1 \text { if sex before marriage always, mostly or sometimes }\end{array}$ & 0.50 & 0.35 & 0.41 & 0.41 & $* * *$ \\
\hline $\begin{array}{l}\text { wrong; }=0 \text { otherwise } \\
=1 \text { if sex between } 2 \text { men always, mostly or sometimes }\end{array}$ & 0.15 & 0.13 & 0.11 & 0.11 & $* * *$ \\
\hline wrong; $=0$ otherwise & 0.47 & 0.50 & 0.56 & 0.58 & $* * *$ \\
\hline$=1$ if abortion always or mostly wrong; $=0$ otherwise & 0.27 & 0.32 & 0.32 & 0.26 & * \\
\hline \multicolumn{6}{|l|}{ Age at first het. intercourse } \\
\hline Aged 13-15 & 0.22 & 0.32 & 0.27 & 0.28 & $* * *$ \\
\hline Aged 16-17 & 0.36 & 0.39 & 0.42 & 0.41 & $* *$ \\
\hline Aged 18-19 & 0.23 & 0.18 & 0.18 & 0.18 & $* * *$ \\
\hline
\end{tabular}


Aged 20+

0.19

0.12

0.14

0.13

Importance for a successful marriage/long term relationship

$=1$ if income very, quite important; $=0$ otherwise

0.72

0.71

0.72

0.73

$=1$ if children very important; $=0$ otherwise

0.32

0.27

0.28

0.28

$=1$ if unfaithfulness always or mostly wrong; $=0$

otherwise

\begin{tabular}{rrrr}
0.66 & 0.71 & 0.71 & 0.66 \\
\hline 832 & 380 & 1201 & 747 \\
\hline
\end{tabular}

No of obs.

1201

Test of significant differences between London and elsewhere: ${ }^{* *} p<0.01,{ }^{* *} p<0.05,{ }^{*} p<0.1$ 
Table 2: Average values of the variables used in the probit of table 3.

\begin{tabular}{|c|c|c|}
\hline & Client & $\begin{array}{l}\text { Non- } \\
\text { client }\end{array}$ \\
\hline Age & 34.83 & 34.82 \\
\hline Number of Children & 1.03 & 1.33 \\
\hline$=1$ if ever married, 0 otherwise & 0.60 & 0.70 \\
\hline$=1$ if never married but ever cohabited, 0 otherwise & 0.11 & 0.14 \\
\hline$=1$ if Degree level qualification; $=0$ otherwise & 0.25 & 0.24 \\
\hline$=1$ if a-levels/as-levels/slc higher grade $;=0$ otherwise & 0.15 & 0.11 \\
\hline$=1$ if 0 -level/other; $=0$ otherwise & 0.46 & 0.47 \\
\hline$=1$ if No education; $=0$ otherwise & 0.14 & 0.18 \\
\hline$=1$ if Professional $/$ managerial; $=0$ otherwise & 0.07 & 0.09 \\
\hline$=1$ if Technical/Managerial; $=0$ otherwise & 0.33 & 0.33 \\
\hline$=1$ if skilled manual or non-manual; $=0$ otherwise & 0.40 & 0.41 \\
\hline$=1$ if partly skilled; $=0$ otherwise & 0.13 & 0.12 \\
\hline$=1$ if unskilled; $=0$ otherwise & 0.04 & 0.06 \\
\hline$=1$ if partner outside UK in the last 5 years; $=0$ otherwise & 0.29 & 0.09 \\
\hline$=1$ if had unsafe het. sex in last year; $=0$ otherwise & 0.14 & 0.06 \\
\hline$=1$ if ever a smoker; $=0$ otherwise & 0.61 & 0.54 \\
\hline$=1$ if ever injected drugs or other substances; $=0$ otherwise & 0.06 & 0.03 \\
\hline$=1$ if high or medium alcohol consumption; $=0$ otherwise & 0.21 & 0.14 \\
\hline No. of new het. sex partners, last year & 1.04 & 0.36 \\
\hline Number of occasions of het. sex in last 4 weeks & 5.60 & 5.84 \\
\hline$=1$ if belongs to any religion now $=0$ otherwise & 0.45 & 0.41 \\
\hline $\begin{array}{l}=1 \text { if sex before marriage always, mostly or sometimes wrong; }=0 \\
\text { otherwise } \\
=1 \text { if sex between } 2 \text { men always, mostly or sometimes wrong; }=0\end{array}$ & 0.10 & 0.12 \\
\hline otherwise & 0.51 & 0.55 \\
\hline$=1$ if abortion always or mostly wrong; $=0$ otherwise & 0.24 & 0.30 \\
\hline \multirow{2}{*}{\multicolumn{3}{|c|}{ Age at first het. intercourse }} \\
\hline Aged 13-15 & & 0.26 \\
\hline Aged 16-17 & 0.35 & 0.41 \\
\hline Aged 18-19 & 0.16 & 0.19 \\
\hline Aged 20+ & 0.13 & 0.14 \\
\hline \multicolumn{3}{|l|}{ Importance for a successful marriage/long term relationship } \\
\hline$=1$ if income very, quite important $;=0$ otherwise & 0.80 & 0.71 \\
\hline$=1$ if children very important; $=0$ otherwise & 0.24 & 0.29 \\
\hline
\end{tabular}


$=1$ if unfaithfulness always or mostly wrong; $=0$ otherwise

\begin{tabular}{rrr}
0.60 & 0.70 & $* * *$ \\
& & \\
0.20 & 0.13 & $* * *$ \\
0.14 & 0.13 & \\
0.41 & 0.46 & \\
0.25 & 0.29 & \\
\cline { 1 - 1 } 404 & 2,756 &
\end{tabular}

London

Urban/city centre - not london

Suburban residential

Country town/village

No of obs.

For the non-dummy variables the ranges of variables are as follows:

age: 26 to 44; number of children: 0 to 8; number of new het. Partners: 0 to 55; number of occasions of het. Sex: 0 to 56

Test of significant differences: ${ }^{* * *} p<0.01,{ }^{* *} p<0.05,{ }^{*} p<0.1$ 
Table 3: Probit estimations of Ever Paid for Sex.

\begin{tabular}{|c|c|c|c|c|c|}
\hline $\begin{array}{l}\text { Dependent variable }=1 \text { if ever paid for sex; }=0 \\
\text { otherwise. }\end{array}$ & Demographics & $\begin{array}{l}\text { With } \\
\text { risky }\end{array}$ & $\begin{array}{l}\text { With } \\
\text { free sex }\end{array}$ & Views & Relationships \\
\hline Age & $\begin{array}{l}0.003^{\star *} \\
{[0.001]}\end{array}$ & $\begin{array}{l}0.004^{* * *} \\
{[0.001]}\end{array}$ & $\begin{array}{l}0.004^{* * *} \\
{[0.001]}\end{array}$ & $\begin{array}{l}0.004^{* * *} \\
{[0.001]}\end{array}$ & $\begin{array}{l}0.004^{\star * \star} \\
{[0.001]}\end{array}$ \\
\hline Number of children & $\begin{array}{l}-0.015^{\star *} \\
{[0.006]}\end{array}$ & $\begin{array}{l}-0.013^{* *} \\
{[0.006]}\end{array}$ & $\begin{array}{l}-0.012^{* *} \\
{[0.006]}\end{array}$ & $\begin{array}{l}-0.011^{*} \\
{[0.006]}\end{array}$ & $\begin{array}{l}-0.012^{* *} \\
{[0.006]}\end{array}$ \\
\hline$=1$ if ever married, 0 otherwise & $\begin{array}{l}-0.048^{* * *} \\
{[0.016]}\end{array}$ & $\begin{array}{l}-0.022 \\
{[0.015]}\end{array}$ & $\begin{array}{l}-0.011 \\
{[0.016]}\end{array}$ & $\begin{array}{l}-0.013 \\
{[0.016]}\end{array}$ & $\begin{array}{l}-0.015 \\
{[0.016]}\end{array}$ \\
\hline $\begin{array}{l}=1 \text { if never married but ever cohabited, } 0 \\
\text { otherwise }\end{array}$ & $\begin{array}{l}-0.062^{\star \star \star} \\
{[0.022]}\end{array}$ & $\begin{array}{l}-0.042^{*} \\
{[0.021]}\end{array}$ & $\begin{array}{l}-0.026 \\
{[0.022]}\end{array}$ & $\begin{array}{l}-0.027 \\
{[0.022]}\end{array}$ & $\begin{array}{l}-0.028 \\
{[0.021]}\end{array}$ \\
\hline \multicolumn{6}{|l|}{ Area Type (ref: country town or village) } \\
\hline London & $\begin{array}{l}0.054^{\star * *} \\
{[0.020]}\end{array}$ & $\begin{array}{l}0.031^{*} \\
{[0.018]}\end{array}$ & $\begin{array}{l}0.028 \\
{[0.018]}\end{array}$ & $\begin{array}{l}0.028 \\
{[0.018]}\end{array}$ & $\begin{array}{l}0.029^{*} \\
{[0.018]}\end{array}$ \\
\hline Urban/city centre - not London & $\begin{array}{l}0.021 \\
{[0.020]}\end{array}$ & $\begin{array}{l}0.016 \\
{[0.019]}\end{array}$ & $\begin{array}{l}0.015 \\
{[0.019]}\end{array}$ & $\begin{array}{l}0.018 \\
{[0.019]}\end{array}$ & $\begin{array}{l}0.018 \\
{[0.019]}\end{array}$ \\
\hline Surburban residential & $\begin{array}{l}0.004 \\
{[0.015]}\end{array}$ & $\begin{array}{l}0.005 \\
{[0.015]}\end{array}$ & $\begin{array}{l}0.004 \\
{[0.015]}\end{array}$ & $\begin{array}{l}0.006 \\
{[0.015]}\end{array}$ & $\begin{array}{l}0.007 \\
{[0.014]}\end{array}$ \\
\hline \multicolumn{6}{|l|}{ Education dummies (ref: no education) } \\
\hline$=1$ if degree level qualification; $=0$ otherwise & $\begin{array}{l}0.024 \\
{[0.023]}\end{array}$ & $\begin{array}{l}0.034 \\
{[0.022]}\end{array}$ & $\begin{array}{l}0.036 \\
{[0.022]}\end{array}$ & $\begin{array}{l}0.033 \\
{[0.022]}\end{array}$ & $\begin{array}{l}0.040^{*} \\
{[0.023]}\end{array}$ \\
\hline $\begin{array}{l}=1 \text { if a-levels/as-levels/slc higher grade; }=0 \\
\text { otherwise }\end{array}$ & $\begin{array}{l}0.055^{\star *} \\
{[0.024]}\end{array}$ & $\begin{array}{l}0.060^{* * *} \\
{[0.023]}\end{array}$ & $\begin{array}{l}0.060^{* * *} \\
{[0.023]}\end{array}$ & $\begin{array}{l}0.058^{* *} \\
{[0.023]}\end{array}$ & $\begin{array}{l}0.061^{* *} \\
{[0.024]}\end{array}$ \\
\hline$=1$ if 0 -level/other; $=0$ otherwise & $\begin{array}{l}0.027 \\
{[0.019]}\end{array}$ & $\begin{array}{l}0.029 \\
{[0.018]}\end{array}$ & $\begin{array}{l}0.030^{*} \\
{[0.018]}\end{array}$ & $\begin{array}{l}0.027 \\
{[0.018]}\end{array}$ & $\begin{array}{l}0.029 \\
{[0.018]}\end{array}$ \\
\hline \multicolumn{6}{|l|}{ Professional status (ref: unskilled) } \\
\hline$=1$ if professional $/$ managerial; $=0$ otherwise & $\begin{array}{l}-0.070^{* *} \\
{[0.033]}\end{array}$ & $\begin{array}{l}-0.058^{*} \\
{[0.031]}\end{array}$ & $\begin{array}{l}-0.057^{*} \\
{[0.031]}\end{array}$ & $\begin{array}{l}-0.058^{*} \\
{[0.031]}\end{array}$ & $\begin{array}{l}-0.053^{*} \\
{[0.031]}\end{array}$ \\
\hline$=1$ if technical $/$ managerial; $=0$ otherwise & $\begin{array}{l}-0.050^{*} \\
{[0.027]}\end{array}$ & $\begin{array}{l}-0.042^{*} \\
{[0.025]}\end{array}$ & $\begin{array}{l}-0.043^{*} \\
{[0.025]}\end{array}$ & $\begin{array}{l}-0.045^{*} \\
{[0.025]}\end{array}$ & $\begin{array}{l}-0.044^{*} \\
{[0.025]}\end{array}$ \\
\hline $\begin{array}{l}=1 \text { if skilled manual or non-manual; }=0 \\
\text { otherwise }\end{array}$ & $\begin{array}{l}-0.046^{*} \\
{[0.024]}\end{array}$ & $\begin{array}{l}-0.038^{*} \\
{[0.022]}\end{array}$ & $\begin{array}{l}-0.039^{*} \\
{[0.023]}\end{array}$ & $\begin{array}{l}-0.040^{*} \\
{[0.022]}\end{array}$ & $\begin{array}{l}-0.042^{*} \\
{[0.022]}\end{array}$ \\
\hline$=1$ if partly skilled; $=0$ otherwise & $\begin{array}{l}-0.03 \\
{[0.027]}\end{array}$ & $\begin{array}{l}-0.028 \\
{[0.025]}\end{array}$ & $\begin{array}{l}-0.028 \\
{[0.025]}\end{array}$ & $\begin{array}{l}-0.027 \\
{[0.025]}\end{array}$ & $\begin{array}{l}-0.027 \\
{[0.025]}\end{array}$ \\
\hline \multicolumn{6}{|l|}{ Risky behavior } \\
\hline \multicolumn{2}{|c|}{$=1$ if had partner outside UK in the last 5 years; $=0$ otherwise } & $\begin{array}{l}0.125^{\star * *} \\
{[0.016]}\end{array}$ & $\begin{array}{l}0.119^{* * *} \\
{[0.017]}\end{array}$ & $\begin{array}{l}0.119^{* * *} \\
{[0.017]}\end{array}$ & $\begin{array}{l}0.113^{* * *} \\
{[0.016]}\end{array}$ \\
\hline
\end{tabular}


$=1$ if had unsafe het. sex in last year; $=0$ otherwise

$\begin{array}{llll}0.085^{* * *} & 0.075^{* * *} & 0.073^{* * *} & 0.061^{* * *} \\ {[0.021]} & {[0.022]} & {[0.022]} & {[0.022]} \\ 0.024^{*} & 0.023^{*} & 0.024^{*} & 0.017 \\ {[0.012]} & {[0.012]} & {[0.012]} & {[0.013]} \\ 0.068^{* *} & 0.065^{\star *} & 0.064^{* *} & 0.060^{\star *} \\ {[0.030]} & {[0.031]} & {[0.030]} & {[0.030]} \\ 0.033^{* *} & 0.034^{* *} & 0.033^{* *} & 0.037^{* *} \\ {[0.017]} & {[0.017]} & {[0.017]} & {[0.016]}\end{array}$

\section{Free sex}

Number of new het. sex partners, last year

$0.009^{*} \quad 0.009^{* *} \quad 0.009^{*}$

Number of occasions of het. sex in last 4 weeks

$[0.005] \quad[0.005] \quad[0.005]$

$\begin{array}{lll}-0.002 & -0.002 & -0.002\end{array}$

$[0.001] \quad[0.001] \quad[0.001]$

\section{Conservative opinions/religion}

$=1$ if belongs to any religion now; $=0$ otherwise

$0.022^{*} \quad 0.025^{* *}$

[0.013] [0.013]

$-0.02-0.015$

$=1$ if sex before marriage always, mostly or sometimes wrong; $=0$ otherwise

[0.017] [0.018]

$=1$ if sex between 2 men always, mostly or sometimes wrong; =0 otherwise

$0.002-0.002$

[0.012] [0.012]

$=1$ if abortion always or mostly wrong; $=0$ otherwise

$-0.021-0.016$

[0.015] [0.015]

\section{Age at first het. intercourse (ref: 16/17)}

Aged 13-15

$0.041^{* \star *}$

[0.015]

Aged 18-19

$-0.009$

[0.017]

Aged 20+

0.009

[0.017]

\section{Attitudes to Relationships}

Importance for a successful marriage/long term relationship

$=1$ if income very, quite important; $=0$ otherwise

$0.045^{* * *}$

[0.014]

$=1$ if children very important; $=0$ otherwise

$=1$ if unfaithfulness always or mostly wrong; $=0$ otherwise

Standard errors in brackets

${ }^{* * *} p<0.01,{ }^{* *} p<0.05,{ }^{*} p<0.1$ 
Table 4: Probit estimations of Ever Paid for Sex for the London and Non London sub-samples

$\begin{array}{lll}\text { Dependent variable }=1 \text { if ever paid for sex; }=0 \text { otherwise. } & \begin{array}{l}\text { Non- } \\ \text { London }\end{array} & \begin{array}{l}\text { London } \\ \hline \text { Age }\end{array} \\ \text { Number of children } & 0.006^{* *} & 0.003^{* *} \\ & {[0.003]} & {[0.001]} \\ =1 \text { if ever married, } 0 \text { otherwise } & -0.016 & -0.011^{*} \\ & {[0.017]} & {[0.006]} \\ =1 \text { if never married but ever cohabited, } 0 \text { otherwise } & -0.041 & -0.012 \\ & {[0.032]} & {[0.017]} \\ & -0.032 & -0.029\end{array}$

\section{Education dummies (ref: no education)}

$=1$ if degree level qualification; $=0$ otherwise

$\begin{array}{ll}0.139^{* * *} & 0.02 \\ {[0.048]} & {[0.026]} \\ 0.131^{* * *} & 0.051^{* *} \\ {[0.048]} & {[0.025]} \\ 0.047 & 0.025 \\ {[0.041]} & {[0.019]}\end{array}$

Professional status (ref: unskilled)

$-0.055 \quad-0.053$

[0.081] [0.035]

$=1$ if technical $/$ managerial; $=0$ otherwise

$-0.078 \quad-0.038$

$=1$ if skilled manual or non-manual; $=0$ otherwise

[0.069] [0.026]

$0.003-0.047^{\star *}$

$=1$ if partly skilled; $=0$ otherwise

[0.067] [0.023]

$0.01 \quad-0.033$

[0.079] [0.026]

\section{Risky behavior}

$0.171^{* * *} \quad 0.097^{* * *}$

[0.029] [0.019]

$=1$ if had unsafe het. sex in last year; $=0$ otherwise $\quad 0.058 \quad 0.060^{* *}$

[0.052] [0.023]

$=1$ if ever a smoker; $=0$ otherwise $\quad 0.006 \quad 0.018$

$=1$ if ever injected drugs or other substances; $=0$ otherwise $\quad-0.007 \quad 0.066^{*}$ 
$=1$ if high or medium alcohol consumption; =0 otherwise

[0.057] [0.034]

$0.080^{* *} \quad 0.031^{*}$

[0.037] [0.018]

Free sex

Number of new het. sex partners, last year

$0.006 \quad 0.011^{*}$

Number of occasions of het. sex in last 4 weeks

[0.007] [0.006]

$-0.003 \quad-0.001$

[0.003] [0.001]

\section{Conservative opinions/religion}

$=1$ if belongs to any religion now; $=0$ otherwise

$0.051^{*} \quad 0.02$

[0.028] [0.014]

$=1$ if sex before marriage always, mostly or sometimes wrong; =0 otherwise

$0.005 \quad-0.021$

[0.039] [0.020]

$=1$ if sex between 2 men always, mostly or sometimes wrong; =0 otherwise

$0.003 \quad-0.005$

[0.029] [0.013]

$=1$ if abortion always or mostly wrong; $=0$ otherwise

$0.008 \quad-0.015$

[0.032] [0.016]

Age at first het. intercourse (ref: 16/17)

Aged 13-15

$0.067^{*} \quad 0.037^{* *}$

Aged 18-19

[0.037] [0.016]

$-0.043-0.004$

Aged 20+

[0.034] [0.019]

$-0.007 \quad 0.012$

\section{Attitudes to Relationships}

[0.041] [0.019]

Importance for a successful marriage/long term relationship

$=1$ if income very, quite important; $=0$ otherwise

$0.013 \quad 0.051^{* * *}$

[0.032] [0.015]

$=1$ if children very important; $=0$ otherwise

$-0.012-0.030$ *

[0.031] [0.015]

$=1$ if unfaithfulness always or mostly wrong; $=0$ otherwise

$-0.042^{*} \quad-0.021$

[0.025] [0.014]

Observations

832

2,328

Standard errors in brackets

${ }^{* * *} p<0.01,{ }^{* *} p<0.05,{ }^{*} p<0.1$ 
